BUDGETING : Journal of Business, Management and Accounting

Volume 2, Nomor 1, Desember 2020

e-ISSN: 2715-2480

p-ISSN: 2715-1913

DOI : https://doi.org/10.31539/budgeting.v2i1.1235

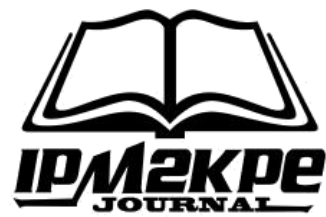

\title{
INTEGRITAS LAPORAN KEUANGAN \\ BERDASARKAN GOOD CORPORATE GOVERNANCE
}

\author{
Rizky Kurniawan M. Nur', Moh. Halim² ${ }^{2}$ Elok Fitriya ${ }^{3}$ \\ Univeritas Muhammadiyah Jember ${ }^{1,2,3}$ \\ rizkyucoy88@gmail.com ${ }^{1}$
}

\begin{abstract}
ABSTRAK
Tujuan penelitian ini adalah untuk menguji pengaruh good corporate governance, kepemilikan institusional dan kepemilikan manajemen terhadap integritas laporan keuangan pada perusahaan pertambangan. Metode penelitian ini menggunakan metode kuantitatif dengan populasi sampel yang diamati adalah seluruh perusahaan pertambangan di Bursa Efek Indonesia (BEI) periode 2016-2018. Hasil penelitian menunjukkan bahwa $R$ square (koefisien determinasi) good corporate governance adalah sebesar 0,127. Adapun kepemilikan institusional memiliki nilai signifikansi $0,192(>0,05)$ dengan koefisien beta (1) sebesar -0,642, sedangkan kepemilikan manajemen menunjukkan nilai signifikansi $0,037(<0,05)$ dengan nilai koefisien beta (2) 0,126. Simpulan, variabel good corporate governance hanya dapat menjelaskan variasi integritas laporan keuangan hanya sebesar $12,7 \%$, sedangkan sisanya $87,3 \%$ dijelaskan oleh variabel-variabel lain yang tidak diamati dalam penelitian. Adapun kepemilikan institusional menunjukkan adanya pengaruh positif dan signifikan terhadap integritas laporan keuangan, sedangkan kepemilikan manajemen menunjukkan hasil yang tidak berpengaruh terhadap integritas laporan keuangan.
\end{abstract}

Kata Kunci: Good Corporate Governance, Integritas Laporan Keuangan, Kepemilikan Institusional, Kepemilikan Manajemen

\section{ABSTRACT}

The purpose of this study was to examine the effect of good corporate governance, institutional ownership and management ownership on the integrity of financial statements in mining companies. This research method uses quantitative methods with the sample population observed are all mining companies on the Bursa Efek Indonesia (BEI) for the period 2016-2018. The results showed that the $R$ square (coefficient of determination) good corporate governance was 0.127. Meanwhile, institutional ownership has a significance value of 0.192 (> 0.05) with a beta coefficient (1) of 0.642 , while management ownership shows a significance value of $0.037(<0.05)$ with a beta coefficient value (2) of 0.126. In conclusion, the variable good corporate governance can only explain the variation in the integrity of financial statements by only $12.7 \%$, while the remaining $87.3 \%$ is explained by other variables not observed in the study. Meanwhile, institutional ownership shows a positive and significant impact on the integrity of financial statements, while management ownership shows results that do not affect the integrity of financial statements.

Keywords: Good Corporate Governance, Integrity of Financial Statements, Institutional Ownership, Management Ownership 


\section{PENDAHULUAN}

Laporan keuangan merupakan suatu penyajian terstruktur dari posisi keuangan dan kinerja suatu entitas yang bertujuan untuk menyediakan informasi mengenai posisi keuangan perusahaan dalam kondisi tertentu (IAI, 2007). Informasi yang disajikan dalam hasil laporan keuangan nantinya akan banyak yang menggunakannya, diantaranya yaitu kreditur, investor, karyawan, pemerintah dan pemakai lain yang nantinya akan berhubungan dengan pengambilan sebuah keputusan ekonomi di dalam suatu perusahaan. Oleh karena itu, dengan banyaknya pengguna laporan keuangan untuk menghasilkan sebuah keputusan ekonomi dalam sebuah perusahaan, maka penyajian laporan keuangan di sebuah perusahaan haruslah disajikan dalam integritas yang tinggi.

Perusahaan-perusahaan yang terdaftar di Bursa Efek Indonesia yang sahamnya diperjualbelikan secara bebas kepada masyarakat sangat perlu menyajikan laporan keuangan dengan tingkat integritas yang tinggi. Menurut FASB (1980) dalam SFAC No. 2, karakteristik-karakteristik kualitatif informasi akuntansi seperti relevan, objectivity dan reliable merupakan tiga karakteristik utama yang harus ada di dalam laporan keuangan agar informasi dalam laporan tersebut bisa dikatakan bermanfaat dalam pengambilan keputusan. Informasi di dalam laporan keuangan bisa dikatakan sebuah informasi yang relevan adalah apabila informasi tersebut bisa memberikan pengaruh pada pengguna laporan keuangan untuk menguatkan atau mengubah harapan pengguna laporan keuangan.

Informasi laporan keuangan yang bisa dikatakan reliable adalah apabila informasi keuangan tersebut disajikan dengan tidak membuat pengguna laporan keuangan bingung, bebas dari kesalahan, andal serta dapat dipercaya. Menurut IAI (2007), informasi dapat dikatakan andal jika bebas dari pengertian yang menyesatkan, adanya kesalahan material dan dapat diandalkan oleh penguna laporan keuangan sebagai penyajian yang tulus atau jujur yang seharusnya disajikan atau yang secara wajar diharapkan dapat disajikan sehingga mengurangi munculnya manipulasi akuntansi

Alasan peneliti memilih perusahaan pertambangan adalah karena perusahaan pertambangan yang ada di Indonesia pernah mengalami kasus manipulasi dalam penyajian laporan keuangan yang juga mengindikasikan lemahnya integritas dalam penyajian laporan keuangan, misalkan PT. Arutmin Indonesia, PT. Kaltim Prima Coal, 
dan induk perusahaan tersebut yaitu PT. Bumi Resources Tbk. Perushaan-perusahaan pertambangan tersebut pernah melakukan manipulasi atau rekayasa laporan penjualan yang menyebabkan negara mengalami kerugian hingga mencapai US\$ 620,49 juta. (Wijaya, 2010).

Good Corporate Governance (GCG) semakin menjadi perhatian karena banyak kasus-kasus menipulasi laporan keuangan telah terungkap (Astria, 2011). Demi mencapai sebuah keseimbangan dalam pengelolaan perusahaan, harus ada yang mengatur hubungan antara dewan komisaris, direksi dan manajemen di dalam suatu perusahaan. Perusahaan yang baik harusnya sudah menerapkan dan memenuhi prinsipprinsip GCG yaitu fairness, transparancy, accountability dan responsibility. Menurut Arief \& Bambang (2007) keempat laporan tersebut penting karena penerapan prinsipprinsip GCG tersebut secara konsisten terbukti dapat meningkatkan kualias laporan keuangan, karena seperti dijelaskan sebelumnya bahwa laporan keuangan yang baik harus memenuhi kriteria utama yaitu relevan, objectivity dan reliable yang bisa memudahkan para pengguna laporan keuangan dalam pengambilan keputusan ekonomi.

Mahasiswa akuntansi merupakan calon akuntan, sehingga para akademisi sangat perlu meningkatkan kurikulum pendidikan tentang etika yang akan dihadapi dalam mengidentifikasi suatu masalah pada saat terjadinya dilema bisnis. Elias (2010) berpendapat bahwa mahasiswa akuntansi sekarang adalah para profesional di masa depan dan dengan pendidikan etika yang baik diharapkan dapat menguntungkan profesinya dalam jangka panjang.

\section{KAJIAN TEORI}

\section{Agency Theory}

Agency theory atau teori keagenan menjelaskan tentang hubungan antara dua pihak yaitu prinsipal dan agen. Teori mengenai hubungan keagenan ini digunakan dalam rangka untuk memahami corporate governance lebih dalam. Menurut Jensen \& Meckling (1976), hubungan keagenan adalah sebuah kontrak antara manajer (agent) dengan investor (principal). Bentuk hubungan keagenan terdiri dari dua bentuk, yaitu antara manajer dan pemegang saham (shareholders) dan antara manajer dan pemberi pinjaman (bondholders). 


\section{Good Corporate Governance}

Good corporate governance adalah the roles of shareholders, directors and other managers in corporate decision making. Menurut Susiana \& Herawaty, (2007) good governance merupakan tata kelola yang baik pada suatu usaha yang dilandasi oleh etika profesional dalam berusaha atau berkarya. Pada prinsipnya tujuan corporate governance adalah menciptakan nilai bagi pihak yang berkepentingan. Pihak-pihak tersebut adalah pihak internal yang meliputi dewan komisaris, direksi, karyawan dan pihak eksternal yang berkepentingan.

\section{Integritas Laporan Keuangan}

Menurut Mayangsari (2003) integritas laporan keuangan adalah sejauh mana laporan keuangan yang disajikan menunjukkan informasi yang benar dan jujur. Faktor yang mempengaruhi integritas laporan keuangan yaitu independensi auditor (Mulyadi, 2013). Auditor mempunyai kewajiban untuk bersikap jujur tidak saja kepada manajemen, tetapi juga terhadap pihak ketiga sebagai pemakai laporan keuangan, seperti kreditur, pemilik, maupun calon pemilik (Kasidi, 2007).

\section{Komisaris Independen}

Komisaris independen merupakan sebuah badan dalam perusahaan yang biasanya beranggotakan dewan komisaris yang independen yang berasal dari luar perusahaan yang berfungsi untuk menilai kinerja perusahaan secara luas dan keseluruhan. Komisaris independen bertujuan untuk menyeimbangkan dalam pengambilan keputusan, khususnya dalam rangka perlindungan terhadap pemegang saham minoritas dan pihak-pihak lain yang terkait.

\section{METODE PENELITIAN}

Penelitian ini menggunakan metode kuantitatif. Metode kuantitatif merupakan metode yang data penelitiannya berupa angka dan analisis yang menggunakan statistik (Sugiyono, 2010). Data yang digunakan pada penelitian ini adalah data sekunder. Data sekunder merupakan data yang diperoleh secara tidak langsung melalui media perantara, baik yang dipublikasikan dan tidak dipublikasikan. Data sekunder dalam penelitian ini berupa laporan keuangan dan laporan auditor independen masing-masing 
perusahaan publik periode tahun 2016-2018 serta data perusahan yang diperoleh dari www.idx.co.id. Populasi pada penelitian ini dilakukan pada perusahaan pertambangan yang terdaftar di Bursa Efek Indonesia tahun 2016-2018. Sebagian besar penanaman modal asing dilakukan pada perusahaan yang bergerak di bidang pertambangan dan mempunyai kaitan intern perusahaan yang cukup substansial dengan induk perusahaan di luar negeri (Gunadi, 1994).

Sampel dalam penelitian ini menggunakan metode purposive sampling dengan kriteria sebagai berikut: 1) penelitian ini mengamati perusahaan pertambangan yang terdaftar di Bursa Efek Indonesia selama tahun 2016-2018. Alasan penggunaan perusahaan pertambangan pada penelitian ini adalah karena perusahaan tersebut di Indonesia pernah mengalami penurunan integritas laporan keuangan; 2) perusahaan sampel dikendalikan oleh perusahaan asing dengan persentase kepemilikan $20 \%$ atau lebih; 3) perusahaan selalu melaporkan laporan keuangan ke Bursa Efek Indonesia selama periode 2016-2018.

Metode pengumpulan data yang digunakan dalam penelitian ini adalah metode dokumenter, yaitu teknik pengambilan data dengan cara mengumpulkan, mencatat dan mengkaji data sekunder yang berupa laporan keuangan perusahaan pertambangan yang dipublikasikan oleh Bursa Efek Indonesia. Variabel dalam penelitian ini dibedakan menjadi 2, yaitu: 1) variabel independen (bebas) yang terdiri dari kepemilikan institusional dan kepemilikan manajemen; 2) variabel dependen (terikat) berupa integritas laporan keuangan.

\section{HASIL PENELITIAN}

Uji Signifikansi Parsial (Uji t)

Tabel 1.

Hasil Uji Signifikansi Parsial (Uji t)

\begin{tabular}{|c|c|c|c|c|c|c|}
\hline \multicolumn{7}{|c|}{ Coefficients $^{\mathrm{a}}$} \\
\hline \multirow[t]{2}{*}{ Model } & & \multicolumn{2}{|c|}{ Unstandardized Coefficients } & \multirow{2}{*}{$\begin{array}{c}\begin{array}{c}\text { Standardized } \\
\text { Coefficients }\end{array} \\
\text { Beta } \\
\end{array}$} & \multirow[t]{2}{*}{$\mathbf{t}$} & \multirow[t]{2}{*}{ Sig. } \\
\hline & & B & Std. Error & & & \\
\hline \multirow{3}{*}{1} & $($ Constant $)$ & 2,891 & ,925 & & 3,125 &, 003 \\
\hline & Kep_Inst &,- 642 & ,484 &,- 185 & $-1,326$ &, 192 \\
\hline & Kep_Manaj &, 126 & ,059 & ,299 & 2,146 & 037 \\
\hline
\end{tabular}

Berdasarkan tabel 1, dapat diketahui bahwa nilai signifikan variabel kepemilikan institusi adalah 0,192 dengan nilai koefisien beta $\left(\beta_{1}\right)$ yaitu $-0,642$. Nilai sig.t $0,192>$ 
0,05. Hal ini menunjukkan bahwa kepemilikan institusi berpengaruh secara positif dan signifikan terhadap integritas laporan keuangan, maka ini bermakna bahwa semakin tinggi sifat kepemilikan institusi maka akan semakin tinggi integritas laporan keuangan diterima.

Adapun nilai signifikan variabel kepemilikan manajemen adalah 0,037 dengan nilai koefisien beta $\left(\beta_{2}\right)$ yaitu 0,126 . Nilai sig.t $0,037<0,05$ mengindikasikan bahwa kepemilikan manajemen tidak berpengaruh terhadap integritas laporan keuangan, maka semakin tinggi kepemilikan manajemen maka semakin rendah integritas laporan keuangan.

\section{Uji Determinan $\left(\mathbf{R}^{2}\right)$}

Tabel 2.

Uji Determinasi $\left(\mathbf{R}^{2}\right)$

\begin{tabular}{|c|c|c|c|c|c|c|}
\hline \multicolumn{7}{|c|}{ Model Summary ${ }^{b}$} \\
\hline \multirow[t]{2}{*}{ Model } & \multirow[t]{2}{*}{$\mathbf{R}$} & \multirow[t]{2}{*}{ R Square } & \multirow{2}{*}{$\begin{array}{c}\text { Adjusted } R \\
\text { Square }\end{array}$} & \multirow[t]{2}{*}{ Std. Error of the Estimate } & \multicolumn{2}{|c|}{ Change Statistics } \\
\hline & & & & & R Square Change & F Change \\
\hline 1 & $356^{\mathrm{a}}$ & , 127 &, 088 & 4,71842 &, 127 & 3,259 \\
\hline
\end{tabular}

Data tabel 2 menunjukkan bahwa hasil $R$ square (koefisien determinasi) adalah sebesar 0,127 . Hal ini berarti variasi integritas laporan keuangan hanya dapat dijelaskan oleh variabel good corporate governance sebesar 12,7\%, sedangkan sisanya 87,3\% dijelaskan oleh variabel-variabel lain yang tidak dimasukkan dalam model.

\section{PEMBAHASAN}

Good corporate governance (GCG) secara definitif merupakan sistem yang mengatur dan mengendalikan perusahaan yang menciptakan nilai tambah (value added) untuk semua stakeholder (Halimatusadiah \& Gunwan, 2014). Ada dua hal yang ditekankan dalam konsep ini: pertama, pentingnya hak pemegang saham untuk memperoleh informasi dengan benar dan tepat pada waktu; kedua, kewajiban perusahaan untuk melakukan pengungkapan (disclosure) secara akurat, tepat waktu dan transparan terhadap semua informasi kinerja perusahaan, kepemilikan dan stakeholder.

Kepemilikan institusional didefinisikan sebagai sejumlah proporsi saham yang dimiliki oleh institusi. Semakin terkonsentrasi kepemilikan saham dalam suatu perusahaan, maka pengawasan yang dilaksanakan oleh pemilik akan semakin efektif 
dan efisien sebab manajemen akan semakin berhati-hati (Sujoko \& Subyantoro, 2007). Persentase saham institusi diperoleh dari penjumlahan atas persentase saham perusahaan yang dimiliki oleh perusahaan lain baik yang berada di dalam maupun di luar negeri (Susiana \& Herawaty, 2007).

Melalui proses monitoring secara efektif, kepemilikan institusional mampu mengendalikan pihak manajemen sehingga dapat mengurangi tindakan manajemen laba. Persentase saham tertentu yang dimiliki oleh institusi dapat mempengaruhi proses penyusunan laporan keuangan yang tidak menutup kemungkinan terdapat akrualisasi sesuai kepentingan pihak manajemen (Boediono, 2005). Berdasarkan hasil penelitian, analisis kepemilikan institusional menunjukkan bahwa variabel ini berpengaruh positif terhadap integritas laporan keuangan, sehingga semakin tinggi good corporate governance maka semakin tinggi tingkat integritas laporan keuangan. Hal ini sejalan dengan penelitian Dewi \& Putra (2016) bahwa kepemilikan institusional berpengaruh positif terhadap integritas laporan keuangan.

Kepemilikan manajerial didefinisikan sebagai persentase saham yang dimiliki oleh manajemen yang secara aktif ikut dalam pengambilan keputusan perusahaan yang meliputi komisaris dan direksi (Arief \& Bambang, 2007). Persentase kepemilikan saham ini merupakan persentase saham yang dimiliki oleh manajemen termasuk di dalamnya persentase saham yang dimiliki oleh manajemen secara pribadi (Susiana \& Herawaty, 2007). Rahma (2014) menyatakan bahwa pihak manajerial dalam suatu perusahaan adalah pihak yang secara aktif berperan dalam mengambil keputusan untuk menjalankan perusahaan. Masalah keagenan potensial terjadi apabila pihak manajer tidak memiliki saham mayoritas perusahaan, sehingga manajer cenderung bertindak untuk mengejar kepentingannya sendiri dan tidak memaksimumkan nilai perusahaan dalam pengambilan keputusan pendanaan. Dengan demikian, kepemilikan manajerial akan mendorong manajemen untuk meningkatkan nilai perusahaan.

Berdasarkan hasil analisis pada penelitian ini, kepemilikan kepemilikan manajemen tidak berpengaruh terhadap integritas laporan keuangan, yang bermakna bahwa semakin tinggi kepemilikan manajemen maka semakin rendah integritas laporan keuangan. Hal ini sejalan dengan hasil temuan Wardhani \& Samrotun (2020) bahwa kepemilikan manajerial tidak berpengaruh terhadap integritas laporan keuangan. 


\section{SIMPULAN}

Kepemilikan insitusional berpengaruh terhadap integritas laporan keuangan. Hal ini menunjukkan bahwa semakin baik kepemilikan insitusional, maka akan semakin tinggi integritas laporan keuangan. Adapun kepemilikan manajemen menunjukkan hasil yang tidak berpengaruh terhadap integritas laporan keuangan. Hal ini bermakna bahwa semakin tinggi kepemilikan manajemen, maka semakin rendah integritas laporan keuangannya.

Variasi integritas laporan keuangan hanya dapat menjelaskan variabel good corporate governance sebesar $12,7 \%$, sedangkan sisanya $87,3 \%$ dijelaskan oleh variabel-variabel lain yang tidak diamati dalam penelitian ini.

\section{DAFTAR PUSTAKA}

Arief, A., \& Bambang, B. (2007). Mekanisme Corporate Governance, Manajemen Laba dan Kinerja Keuangan (Studi pada Perusahaan Go Public Sektor Manufaktur). Simposium Nasional Akuntansi X. Universitas Hasanuddin Makassar

Astria, T. (2011). Analisis Pengaruh Audit Tenure, Struktur Corporate Governance dan Ukuran KAP terhadap Integritas Laporan Keuangan. Skripsi. Universitas Diponogoro

Boediono, G. (2005). Kualitas Laba: Studi Pengaruh Mekanisme Corporate Governance dan Dampak Manajemen Laba dengan Menggunakan Analisis Jalur. Simposium Nasional Akuntansi (SNA) VIII. Solo

Dewi, N. K. H. S., \& Putra, I. M. P. D. (2016). Pengaruh Mekanisme Corporate Governance pada Integritas Laporan Keuangan. E-Jurnal Akuntansi, 15(3), 2269-2296

Elias, R. Z. (2010). The Relationship Between Accounting Student's Love of Money and Their Ethical Perception. Managerial Auditing Journal, 25(3), 269-281

Financial Accounting Standards Board (FASB). (1980). Statement of Financial Accounting Concepts No.2: Qualitative Characteristics of Accounting Information. Diakses dari https://www.fasb.org/

Gunadi, G. (1994). Transfer Pricing, Suatu Tinjauan Akuntansi, Manajemen dan Pajak. Jakarta: Bina Rena Pariwara

Halimatusadiah, E., \& Gunwan, B. (2014). Analisis Penerapan Good Corporate Governance dalam Mengoplimalkan Pelaksanaan Sistem Informasi Akuntansi (Studi pada PT. Pos Indonesia (Persero)). Jurnal Riset Akuntansi dan Keuangan, 2(1), 300-313

Ikatan Akuntan Indonesia (IAI). (2007). Standar Akuntansi Keuangan. Jakarta: Salemba Empat 
Jensen, M. C., \& Meckling, W. H. (1976). Theory of the Firm: Managerial Behavior, Agency Costs and Ownership Structure. Journal of Financial Economics, 3(1), $305-360$

Kasidi, K. (2007). Faktor-Faktor yang Mempengaruhi Independensi Auditor (Persepsi Manajer Keuangan Perusahaan Manufaktur di Jawa Tengah. Tesis. Universitas Diponegoro.

Mayangsari, S. (2003). Analisis Pengaruh Independensi, Kualitas Audit serta Mekanisme Corporate Governance terhadap Integritas Laporan Keuangan. Simposium Nasional Akuntansi VI. Surabaya

Mulyadi, M. (2013). Sistem Akuntansi, Edisi Tiga, Cetakan Keempat. Jakarta: Salemba Empat

PT. Bursa Efek Indonesia. (2016). Laporan Keuangan dan Tahunan. Diakses dari www.idx.co.id

PT. Bursa Efek Indonesia. (2017). Laporan Keuangan dan Tahunan. Diakses dari www.idx.co.id

PT. Bursa Efek Indonesia. (2018). Laporan Keuangan dan Tahunan. Diakses dari www.idx.co.id

Rahma, A. (2014). Pengaruh Kepemilikan Manajerial, Kepemilikan Institusional dan Ukuran Perusahaan terhadap Keputusan Pendanaan dan Nilai Perusahaan (Studi Kasus pada Perusahaan Manufaktur yang Terdaftar di Bursa Efek Indonesia Periode 2009-2012). Jurnal Bisnis STRATEGI, 23(2), 45-69

Sugiyono, S. (2010). Metode Penelitian Pendidikan Pendekatan Kuantitatif, Kualitatif, dan $R \& D$. Bandung: Alfabeta

Sujoko, S., \& Subyantoro, U. (2007). Pengaruh Struktur Kepemilikan Saham, Leverage, Faktor Intern dan Faktor Ekstern terhadap Nilai Perusahaan. Jurnal Manajemen dan Kewirausahaan, 9(1), 41-48

Susiana, S., \& Herawaty, A. (2007). Analisis Pengaruh Independensi, Mekanisme Corporate Governance dan Kualitas Audit terhadap Integritas Laporan Keuangan. Simposium Nasional Akuntansi X. Universitas Hasanuddin Makassar Wardhani, W. K., \& Samrotun, Y. C. (2020). Pengaruh Kepemilikan Institusional, Kepemilikan Manajerial, Ukuran Perusahaan dan Leverage terhadap Integritas Laporan Keuangan. Jurnal Ilmiah Universitas Batanghari Jambi, 20(2), 475-481

Wijaya, A. (2010). ICW Ungkap Manipulasi Penjualan Batu Bara Grup Bakrie. Diakses dari http://www.tempo.co/read/news/2010/ 02/15/087225895/ICWUngkapManipulasi-Penjualan-Batu-BaraGrup-Bakrie/ 